August 2012

\title{
A System, Society, and Community Perspective on Genocide
}

Adrian M. Gallagher

Follow this and additional works at: https://digitalcommons.usf.edu/gsp

\section{Recommended Citation}

Gallagher, Adrian M. (2012) "A System, Society, and Community Perspective on Genocide," Genocide Studies and Prevention: An International Journal: Vol. 7: Iss. 2: Article 4.

DOI: $10.3138 /$ gsp.7.2/3.166

Available at: https://digitalcommons.usf.edu/gsp/vol7/iss2/4

This Articles is brought to you for free and open access by the Open Access Journals at Digital Commons @ University of South Florida. It has been accepted for inclusion in Genocide Studies and Prevention: An International Journal by an authorized editor of Digital Commons @ University of South Florida. For more information, please contact digitalcommons@usf.edu. 


\title{
A System, Society, and Community Perspective on Genocide
}

\author{
Adrian M. Gallagher \\ University of Leeds
}

The question of why the international community continually fails to prevent genocide remains an ever-present concern. Genocide scholars question how the political will of the politically unwilling remains unaltered by the genocides in Rwanda and Darfur. However, it appears that little consideration has been given to the fact that genocide is open to interpretation. By this I mean that all scholars and policy makers have a view of the world which shapes their understanding of genocide within it. This is important because it helps explain why actors at the international level perceive genocide prevention in a radically different light from one another. With this in mind, the article uses the concepts of an international system, an international society, and an international community to demonstrate how one's worldview has implications on how one understands genocide. These three perspectives help underline the complexities involved as genocide prevention remains dependent on a consensus being forged among actors who do not share a common worldview.

Key words: genocide prevention, international system, realism, international society, the English School, international community, cosmopolitanism

This article incorporates the concept of genocide into Martin Wight's "three traditions" framework in order to put forward a realist-international system, a rationalistinternational society, and a cosmopolitan-international community perspective on genocide in international relations (IR). ${ }^{1}$ The value of this approach is that it enables a three-way dialogue to be forged between competing worldviews that highlights how the assumptions embodied within one's view of international relations shapes one's understanding of issues such as justice, power, and, in this context, genocide. The utility of Wight's approach has seen an upsurge in the three traditions literature over the past two decades as scholars have sought to analyze issues such as humanitarian intervention, globalization, and the security dilemma within this tripartite framework. ${ }^{2}$ To date, there has not been a single article published which analyzes genocide within the context of the three traditions. Accordingly, this article addresses this lacuna and, in so doing, demonstrates how alternative worldviews shape perceptions, interpretations, and understandings of genocide. This is not to suggest that other factors-from the psychological mindset of a leader to the grand strategy of a state-do not also play a role in shaping perceptions, but that at present the discourse tends to overlook the implications of competing worldviews for the issue of genocide prevention.

To put the issue of rival worldviews into context, let us consider a recent debate in the Journal of Genocide Research between Linda Melvern and Stephen Wertheim over whether the Rwandan Genocide could have been prevented. ${ }^{3}$ While many issues were raised, of specific interest here is Melvern's claim that the 2,500 UN peacekeepers in Kenya, 250 US Rangers in Burundi, 800 French troops in the region, and " 80 Italians everywhere!" (to use Wertheim's phrase ${ }^{4}$ ) among others, could and therefore should have been brought together in order to prevent the Rwandan Genocide or at least 
minimize its destruction. ${ }^{5}$ Opposing this view, Wertheim claims that while possible, this was not plausible. ${ }^{6}$ The point here is not to judge whether Melvern or Wertheim is right as that would take an entire article in itself. Rather, the aim is to simply highlight that each perspective embodies a different worldview regarding the potential for cooperation between states. ${ }^{7}$ From an IR perspective, Melvern seemingly upholds a normative approach which posits that since states could have cooperated, they should have, and thus by "pooling" their resources, states could have prevented the Rwandan Genocide. ${ }^{8}$ On the other hand, Wertheim's focus on what is plausible rather than possible reveals a realist approach which stresses the inherent difficulties of cooperation in an anarchical realm (though Wertheim is sympathetic to the idea that the US could have supported the Rwandan Patriotic Front)..$^{9}$ Notably, this example illustrates that the debates that emerge between genocide scholars do not necessarily stem from alternative views of genocide (both Melvern and Wertheim wanted the Rwandan Genocide to be prevented) but instead stem from different worldviews.

Problematically, these worldviews are rarely acknowledged within the discourse. Until this is taken into account, my fear is that scholars and policy makers will continue to talk past one another rather than to each other. By this I mean that because a dialogue is created on a single subject matter-in this case, genocide-the actors involved assume they are talking about the same thing, whereas in fact, they have a fundamentally different understanding of genocide prevention that stems from their worldview. While such thinking is increasingly accepted in political science, ${ }^{10}$ this remains an unexplored theme in genocide studies. ${ }^{11}$ Addressing this lacuna, this article incorporates genocide into the three traditions framework in order to illustrate how one's worldview shapes one's understanding of genocide within it. The hope is that through deconstructing alternative worldviews on genocide we can generate valuable insight into how a more fruitful dialogue that aids the prevention of genocide can be constructed.

To do this, the article is structured in a fourfold format. The first section presents a brief overview of the three traditions in order to explain what is meant by an international system, an international society, and an international community perspective. This provides the groundwork for the following three sections, which put forward more in-depth analyses of each outlook to reveal how the assumptions embodied in each worldview have implications on genocide prevention. This is something that needs to be considered carefully within the discipline of genocide studies.

\section{The Three Traditions}

It was in the 1950s that Martin Wight first identified the three traditions of realism, rationalism, and revolutionism as a teaching tool to help students navigate the realistidealist dichotomy that dominated the discipline of IR in the interwar period. ${ }^{12}$ As Andrew Linklater explains, "In his lectures, Wight lamented the way in which debates between realism and utopianism in the interwar years had neglected the via media with its distinct focus on international society." 13 For Wight, there was middle ground to be found between the overt pessimism embodied in realism and the overt optimism embodied in what he labeled revolutionism. Responding to this neglected middle ground, Wight brought the rationalist tradition (which he associated with Hugo Grotius), back into his analysis of international theory. In so doing, Wight developed a threefold analytical framework that, as I have stated, has undergone a revival since it was published posthumously in 1991. Accordingly, this article incorporates the concept of genocide 
International System

Realism

Machiavellian Tradition

Whether driven by human nature (realism) or international anarchy (neorealism), states seek power, security, and survival as a predetermined national interest.
International Society

Rationalism

Grotian Tradition

States engage in communicative dialogue to establish common norms, values, principles, and institutions, thereby creating an international society.
International Community

Revolutionism

Kantian Tradition

International relations progress to the point that a community of humankind is established, thereby fundamentally altering the present

Westphalian-centric view of international relations.

Pessimistic View

Optimistic View

Figure 1 An overview of the Linklater-Wight juxtaposition ${ }^{14}$

into this threefold framework to help shed insight into understanding genocide in international relations.

As stated, Linklater uses Martin Wight's three traditions to equate the tradition of realism with the more pessimistic idea of an international system, the tradition of rationalism with the idea of an international society, and the tradition of revolutionism with the more optimistic idea of an international community. ${ }^{15}$ Understandably, for those not familiar with IR theory, this overview may seem somewhat alien. Thus, in Figure 1 I attempt to bring the Linklater-Wight juxtaposition to life in order to help illustrate the three alternative worldviews prior to integrating the concept of genocide.

It is important to take note of three caveats prior to continuing. First, the spectrum falls foul of failing to recognize "discontinuities of thought" 16 and exclusions of thought, such as gender. ${ }^{17}$ Second, Wight himself feared that reification would only further simplify and distort the three concepts which he himself never published. ${ }^{18}$ While both these points are valid, it seems that the discipline of IR has always been plagued by the problem of classification. Scholars use frames, labels, figures, and models as ways of illustrating the complexities involved. The reality is that if we did not categorize the history of ideas, we would be left bewildered. What is important, then, is that scholars remain aware of the limitations involved while continuing to explain their position as clearly as they can. A third and final caveat is that Wight stressed that "the three traditions are not like three railroad tracks running parallel into infinity. ... The three traditions are streams, with eddies and crosscurrents, sometimes interlacing and never for long confined to their own riverbed." 19 This statement neatly captures the idea of blurred boundaries and underlines the notion that realism, rationalism, and revolutionism should not be viewed as three separate pillars.

Figure 1 simply aims to illustrate that the three traditions of realism, rationalism, and revolutionism represent different and competing worldviews. This is important because one can see that one's position on this spectrum consequently holds implications for how one understands genocide prevention in international relations just as it would with any other concept, such as war, sovereignty, diplomacy, or justice. Each tradition embodies assumptions, and understanding these helps reveal how one's view of 
the world shapes one's view of genocide prevention within it. To consider this further, let us first address the tradition of realism and the idea of an international system.

\section{International System: Realism}

Critics often portray realism in an overly simplistic and crude manner, which in turn allows them to dismiss realism, or at least their representation of realism, with ease. ${ }^{20}$ This is not to suggest that realism does not have its problems, but to acknowledge at the outset that realism does offer insight into understanding international relations. ${ }^{21}$ Perhaps Barry Buzan summarized this position best in "The Timeless Wisdom of Realism?," where he essentially concludes that realism offers us wisdom, but not timeless wisdom. ${ }^{22}$ From this perspective, realism offers insight into the complexities of international relations, but it fails in its attempt to provide objective knowledge claims that are applicable across both time and space. However, the dominance of realism in policy making remains unavoidable: "From 1939 to the present, leading theorists and policy makers have continued to view the world through realist lenses." ${ }^{23}$ It is therefore important to engage with realism for it helps explain why policy makers give low political priority to the issue of genocide prevention.

To return to Linklater's analysis, he equates the tradition of realism with the idea of an international system: "The Hobbesian or Machiavellian perspective represents the anti-progressivist approach to international relations which contends that states belong to an international system in which there is seldom relief from competition and conflict." 24 The statement encapsulates the skepticism embodied in the realist view of international relations. Unlike English School scholars-who champion the idea of an international society-realists tend to see a world of international instability rather than international order. The origins of this instability are traced back to the anarchical structure (neorealism) or human nature (classical realism). ${ }^{25}$ With no world government to constrain the conditions of anarchy or human nature, states remain embroiled in a never-ending competition for power, security, and survival. Essentially, states are locked into this international system of competition and conflict which prevents any potential for progress toward an international society or international community.

To put this logic into the context of genocide studies let us consider Alex Alvarez's work Governments, Citizens and Genocide, in which the author explains that diplomats "are often held hostage to Realpolitik strategies that place a higher value on protecting national security than protecting an oppressed group." 26 The prioritization of national security dictates that the prevention of genocide and mass violence is given little political priority. For instance, in 1975, prior to the Indonesian oppression in East Timor, the Australian ambassador to Indonesia wrote that Australia should assume a "pragmatic rather than a principled stand," because "that is what national interest and foreign policy is all about." ${ }^{27}$ Echoing such sentiment, James Wood, a US deputy assistant secretary of defense, placed Rwanda-Burundi on a list of potential trouble spots only to be informed by a superior: "Take it off the list. . . US national interest is not involved ... we can't put all these silly humanitarian issues on lists like important problems like the Middle East and North Korea and so on." 28 Similarly, as Slobodan Milošević engineered a process of destruction and dispossession in the former Yugoslavia, George Bush's secretary of state James Baker repeatedly stated, "We don't have a dog in this fight." 29 The attitude expressed through these statements underlines the central point that genocide prevention is not considered to be in a state's national interest. Because of this, policy makers view genocide prevention as somewhat altruistic and part of an unrealistic 
foreign policy agenda. It is important to consider, however, that this does not necessarily represent an amoral or immoral position, even though it is obviously a highly contentious issue. ${ }^{30}$

Although realists would like to live in a world without problems such as genocide, they do not see how such problems can be resolved without the establishment of a world government. To go back to the aforementioned debate over the potential for cooperation between states, realists argue that international institutions such as the United Nations do not have the power to "mitigate anarchy's constraining effects on interstate cooperation." ${ }^{31}$ In other words, because there is no world government, states operate within a climate of mistrust and fear (the security dilemma ${ }^{32}$ ). This zero-sum environment dictates that state $x$ will only cooperate with state $y$ if state $x$ perceives that it will gain more out of the agreement than state $y$ (and vice versa); for realists, this explains why there is so little cooperation at the international level. This represents a relative gains approach as opposed to an absolute gains approach which is upheld by those that favor the idea of an international society. Such understanding helps explain why realists view genocide as just another insoluble problem as they reject the so-called idealistic belief that "no problems-however hopeless they may appear to be-are really insoluble, given well-meaning, well-financed, and competent efforts." ${ }^{33}$ In sum, realists do not credit institutions such as the UN with any real power to help foster cooperation between states which, when juxtaposed with the fact that there is no world government, dictates that there is no functioning collective security system to address problems such as genocide.

Moreover, without a world government or a functioning collective security system, realists remain fearful of states getting involved in altruistic moral crusades. Thus, a normative argument emerges as realists claim that "the path of justice and honour involves one in danger." ${ }^{34}$ In other words, genocide prevention is a classic example of moral overreach, for as Morgenthau succinctly stated, while the individual has the right to say, "Let justice be done, even if the world perish," the state does not have the right to say this on its citizens' behalf. ${ }^{35}$ Since realists reject the idea that states have a moral obligation to anyone other than their own citizens, they have tended to view international normative developments such as the 1948 United Nations Convention on the Prevention and Punishment of the Crime of Genocide (UNCG) as humanitarian concerns that are of little real concern to a state's national interests. From this perspective states should not send-or let the UN send-their "sons and daughters" to die "saving strangers." ${ }^{36}$ In addition to this, realists claim that so-called humanitarian intervention is nothing more than a "Trojan horse." ${ }^{37}$ Political elites may speak with a moral tongue when intervening in a certain state but they pursue ulterior motives. Thus, a secondary moral argument arises as realists claim that state sovereignty and nonintervention help protect weaker countries from the imperialistic agendas of more powerful ones. Accordingly, this realist framework embodies a moral rationale.

For realists, whether right or wrong, humankind has divided itself up into states. It is therefore unrealistic to ignore the reality that policy makers create policy on behalf of states rather than on behalf of humankind. Yet as shall be discussed below, this is precisely what cosmopolitans advocate. Realists claim that when states do cooperate, they do so only to further the national interest. For example, long-term collective security strategies are adopted when attempting to prevent crimes such as nuclear proliferation, international terrorism, drug trafficking, and piracy at the international level..$^{38}$ Using 
realist logic, it would seem that policy makers perceive that such crimes outstrip the individual security capacity of states who then work collectively to address this security deficit. Accordingly, the collective interest furthers the national interest within such specific contexts. The fact that there is no long-term collective security strategy regarding genocide reflects that policy makers do not perceive genocide as posing an international threat. Such understanding only goes to restate the point that when it comes to genocide prevention, policy makers do not perceive that they have a "dog in the fight" and in turn do not treat the prevention of genocide as a matter of national interest.

Prior to highlighting the counter-perspectives put forward by English School scholars (international society) and cosmopolitans (international community) it is important to stress that further interdisciplinary research needs to be done. For example, realists have to consider whether their view of genocide stems from their understanding of human nature, cooperation, national interest, anarchical structure-a mix of theseor, more importantly, genocide itself. ${ }^{39}$ By this I mean that despite their having a pessimistic view of human nature, a narrow understanding of national interest, a relative gains approach toward cooperation, and/or a neorealist belief that the anarchical system can push states to behave in certain ways, realists do accept that on certain issues states do cooperate within the anarchical realm. This acceptance of cooperation is important because it highlights that the realist view-that genocide prevention is not within the national interest of states-stems not from their view of cooperation, human nature, and so forth, but their view of genocide. In other words, realists do not believe that genocide poses a security threat to states. It is this perception of genocide, therefore, that drives realists to claim that states should not engage in genocide prevention unless there are matters of national interest at stake. However, a problem arises as realists have not spent any significant amount of time questioning whether genocide does in fact have an impact on international order. Simply speaking, they have a view of genocide but have not actually studied genocide in any great detail. This brings us back to the article's opening claim that more interdisciplinary research on the relationship between one's worldview and one's understanding of genocide within it is needed.

At present, it appears that the realist view of genocide is built on a set of undertheorized assumptions. This was put into perfect context in the aftermath of the Rwandan Genocide as hard-line realist Henry Kissinger stated,

At least in Bosnia we did something-maybe too late-but in Rwanda hundreds of thousands were killed. [Rwanda] is not a country of strategic importance for the United States; you cannot define a national interest that would take us there. And yet, there, I tend to think I personally would have supported an intervention. It would have been a violation of what ordinarily is my principle. Ordinarily I feel that you should not risk American lives for objectives where you cannot explain to the mothers why you did it.... [Yet] my instinct tells me we should have done it in Rwanda. ${ }^{40}$

The statement neatly captures much of the rationale set out above as Kissinger highlights that states should only engage in complex foreign policy matters when there are national interests at stake. From a moral perspective, the prioritization of the national interest is justified on the grounds that the lives of citizens should not be risked for anything other than national security. While one could raise the point that many grieving mothers may accept genocide prevention as a "just cause," the interesting point 
is that Kissinger favors intervention even though it violates his ordinary principle (by which he means the assumptions set out above). Kissinger's omission is very interesting for the following concluding point: if realists accept that they may be willing to violate their ordinary principles when it comes to genocide prevention, then is it not time that realists reformulate their ordinary principles so that they did not have to violate them in the first place ${ }^{41}$ Otherwise, realism provides us with a theory of international relations except at those times when genocide is occurring, which notably undermines the entire premise of so-called realism. Therefore, it is worth considering that realists do not hold a monopoly over interpreting reality, which naturally leads us to the two alternative perspectives discussed below.

In sum, realists ask us to consider the tragedy that lies at the heart of international relations. ${ }^{42}$ This tragedy stems from the fact that there is no world government to constrain human nature (classical realism) or mitigate the impact of the anarchical structure (neorealism). Because of these factors, genocide represents an insoluble problem; furthermore, genocide prevention represents an altruistic and dangerous foreign policy agenda that states should not pursue unless there are vital national interests at stake. Until a world government is formed, to think otherwise is simply unrealistic or utopian. Yet of course, counterclaims can be made, which leads us to the international society perspective as English School scholars claim that even without a world government states can and do uphold legal, moral, and political agreements.

\section{International Society: Rationalism}

As stated, the English School approach to international relations-which Wight associated with Hugo Grotius-is also known as the international society approach or the rationalist approach. ${ }^{43}$ All three terms, therefore, are used interchangeably to refer to the English School view that international society represents a via media between the international system advocated by realists and the international community advocated by cosmopolitans (to be discussed below). While the English School's focus on the state and the role of power within international relations has sometimes seen critics label it "realism in drag," as will be discussed, the idea that states have formed a society rather than a system demonstrates a fundamentally different interpretation of international relations, which holds significant implications for how English School scholars view genocide. ${ }^{44}$

To flesh out this idea of an international society let us return to Linklater, who summarizes the meaning of this society approach:

The Grotian tradition occupies the intermediate position since it believes there has been qualified progress in world politics exemplified by the existence of a society of states which places constraints on the state's power to hurt and facilitates international cooperation. States in this condition are orientated towards communicative action-to participation in diplomatic dialogues in which they advance claims and counterclaims with a view of establishing global standards of legitimacy which distinguish between permissible and proscribed behavior. ${ }^{45}$

The statement encapsulates the spirit of the international society approach as English School scholars believe that although societal relations have developed beyond that of an international system, they have not progressed, and indeed are unlikely to progress, to the point of an international community. As a result, international society represents the middle-ground position: there is more to international relations than the 
realist suggests but less than the cosmopolitan desires. ${ }^{46}$ The idea of an international society, therefore, stems from the belief that just as individuals at the domestic level create societies based on the establishment of collective understandings, states create international societies by establishing what Linklater refers to as "global standards of legitimacy." These standards of legitimacy are expressed via the norms, values, principles, and institutions of international relations. ${ }^{47}$ It is claimed that these collective understandings enable and/or constrain the behavior of states, thereby increasing the likelihood of order at the international level. ${ }^{48}$

From this perspective, the UNCG represents a normative reaction to the Nazi atrocity which was later labeled genocide. By this I mean that the Nazi genocide acted as a catalyst which altered international legal, moral, and political expectations, thus changing international society's understanding of "rightful conduct." ${ }^{\text {"9 }}$ For instance, Gareth Evans explains that for 300 years the Westphalian principles that underpinned international relations acted to "institutionalize indifference" in that political leaders were both immune to external accountability and largely indifferent toward the suffering of others within states. ${ }^{50}$ This is not to say that political elites never voiced concern over human rights violations within other states. ${ }^{51}$ Events such as those in Armenia acted as notable precursors for the changes made in the post-World War II era. ${ }^{52}$ The point is that the pattern of institutionalized indifference was deemed to be morally and legally unacceptable in the aftermath of the Nazi genocide. From this perspective, international society's willingness to accept the term genocide and codify it into international law reflected a new global standard of legitimacy. Furthermore, the Nazi genocide had broader implications as it helped shape the discourse on universal human rights. ${ }^{53}$ Such developments reinforce the English School belief that states form a society at the international level by creating collective institutions, rules, norms, values, and principles. These reflect that international relations have progressed to the point that the international system has become an international society.

At this point the genocide scholar may rightly point out that while the UNCG may represent a global standard of legitimacy, so far, political elites have systematically failed to meet the goals of the convention. Of course, English School scholars would not reject this position for it is evident that states have failed to fulfill their legal and moral duties to prevent genocide. ${ }^{54}$ Yet at the same time, one has to consider that since genocide prevention may lead states to complex and dangerous foreign policies, fundamental problems arise from legal, moral, and political perspectives. ${ }^{55}$ Although English School scholars want genocide prevention and favor the idea of collective preventative strategies being forged, they also share some realist fears regarding humanitarian intervention which they believe "exposes the conflict between order and justice at its starkest." 56 The reason for their apprehension is that the debate over humanitarian intervention creates tension between the fundamental principles that are seen to underpin both order (state sovereignty) and justice (universal human rights) in international society. As is well documented, the Charter of the United Nations embodies a dual commitment to both state sovereignty and human rights. ${ }^{57}$ Although the latter took on a subordinate role in $1945,{ }^{58}$ developments since have seen contemporary interpretations of the Charter claim that both state sovereignty and human rights should be understood as ordering principles within international society and that the former should be understood in the conditional rather than the absolute sense as implied by the UNCG and the 2005 formalization of the Responsibility to Protect (R2P)..$^{59}$ 
Notably, this has seen a division arise within the English School between pluralists and solidarists. On the one hand, English School pluralists reject the idea that states can legitimately intervene in other states' internal affairs and uphold the rules of absolute sovereignty and nonintervention on the grounds that these rules help serve international order. ${ }^{60}$ From this perspective, humanitarian intervention acts as a crime against humanity (in a non-legal manner) as it violates the very rules that serve humanity best. ${ }^{61}$ On the other hand, English School solidarists claim that sovereignty should be understood as conditional, human rights as universal, and humanitarian intervention as legitimate if they bring an end to mass atrocity crimes such as genocide. ${ }^{62}$ Critically, both sets of scholars appeal to different empirical developments in their attempts to legitimate their own set of rules. For example, pluralists invoke the UN Charterespecially Article 2 (7) - to claim that sovereignty should be interpreted as absolute. ${ }^{63}$ Solidarists advocate subsequent developments such as the adoption of the UNCG and $\mathrm{R} 2 \mathrm{P}$ in order to demonstrate that sovereignty should be interpreted as conditional. While an assessment of these claims cannot be put forward here, ${ }^{64}$ the division within this one school of thought succinctly illustrates the magnitude of the task at hand, as international society has been constructed upon fundamentally opposing ordering principles. Genocide prevention will remain entrenched in a legal and political quagmire until what Ian Clark refers to as a "tolerable consensus" has been forged between relevant actors at the international level. ${ }^{65}$

A final point worth considering within this analysis of international society is the faith that English School scholars place in the idea of an international society. Indeed it may seem somewhat paradoxical to highlight the moral deficiencies of international society on the one hand but also uphold a commitment to international society on the other. This brings us naturally to the criticism that the English School is state-centric in nature. How can it stress the moral imperfections of the state system yet remain committed to a state-centric approach? This is perhaps best illustrated in Paul Keal's accomplished study, in which he highlights that the laws and ideas embodied within the expansion of international society led it to be constructed on the dispossession of indigenous lands, the dehumanization of indigenous peoples, and ultimately genocide. ${ }^{66}$ From this perspective, the historical evolution of international society should be understood as "morally backward." 67 However, despite Keal accepting this, he upholds an English School approach for he claims that international society remains the most appropriate vehicle for moral progress within contemporary international relations. ${ }^{68}$ In other words, English School scholars accept that states have committed atrocities in the past and will no doubt commit them in the future, but to suggest that an alternative non-state framework can be constructed is a fallacy. Again, it may be possible, but not plausible. As Andrew Hurrell succinctly explains, "The state can certainly be a major part of the problem but remains an unavoidable part of the solution." 69

So where does this leave genocide, the UNCG, and genocide prevention from an English School perspective? English School scholars would illustrate that although the UNCG and R2P have laid some groundwork, much more has to be done to entrench and institutionalize universal moral standards and implement exiting legal commitments. ${ }^{70}$ International law will never cause states to act in a certain way, but it does shape the behavior of states and most of the time states do uphold international legal developments. The problem is that genocide prevention, as discussed, remains highly problematic from a legal, moral, and political perspective. Therefore, English School 
scholars accept that normative developments will not come about quickly as an international consensus needs to be forged in order to implement-not just agree upon-global standards of legitimacy such as the UNCG. The fear is that just as international relations can progress, they can also regress, and the survival of international society requires a consensus being forged over the basic principles of international order. ${ }^{71}$ In essence, English School scholars uphold an evolutionary rather than a revolutionary ethic as they seek to gradually improve international society rather than radically redesign it. It is this latter aspect that this article now turns its attention toward.

\section{International Community: Revolutionism}

The tradition of revolutionism remains the most undertheorized tradition identified by Martin Wight-at least from an English School perspective. For Wight, revolutionism was a hybrid category which captured the "soft" revolutionaries from Kant to Nehru, as well as the "hard" revolutionaries of Jacobins and Marxists. ${ }^{72}$ While the complexities involved in this broad spectrum cannot be addresses here, it is evident that these revolutionary perspectives share common ground in that they act to remind both realism (international system) and rationalism (international society) of the moral imperfections to be found in the present state-centric model. ${ }^{73}$

It is important then to stress that Figure 1 reflects Linklater's focus on Kant's softer revolutionary position and the idea of an international community. As Linklater explains, "The Kantian tradition represents the progressivist tendency in international thought since its members believe in the existence of a latent community of humankind, and are confident that all political actors have the capacity to replace strategic orientations with cosmopolitan political arrangements governed by dialogue and consent rather than power and force." ${ }^{74}$ Perhaps the best way of viewing this Kantian perspective is in terms of what humanity should move away from, rather than exactly what humanity should move toward. For example, a Kantian commitment to humanity implies that we should move away from the present Westphalian, state-centric model as this serves the interests of states rather than the interests of humanity. Yet at the same time there remains significant debate among Kantians as to how societal relations should be ordered instead. ${ }^{75}$ The point of relevance is that this perspective prioritizes the value of humanity over the realist focus on power or the English School focus on order.

To relate this cosmopolitan focus back to the study of genocide, it seems clear that cosmopolitans could use the occurrence of genocide to illustrate how the present state system is failing humanity. In so doing, cosmopolitanism poses a direct challenge to the realist and English School dependency on states and policy makers, which further strengthens the cosmopolitan normative claim that international relations should progress to the point that the security of the individual is given priority over that of the state-while acknowledging that the state has a role to play. ${ }^{76}$ By starting with the individual rather than the state, cosmopolitans break away from the state-centric, top-down focus embodied in both the aforementioned international system and international society perspectives. Martin Shaw's work on global society provides great insight here as he explains that state-centric approaches are limited precisely because they neglect "complex social relations which bind individuals and states."77 Thus, Shaw invokes a more complex formulation of international relations which seeks to understand both relations between and within states, and in so doing invokes the idea of human society. ${ }^{78}$ 
While not a cosmopolitan as such, Shaw's work could be placed within the international community framework as he claims that a new politics of global responsibility needs to be forged that goes beyond the narrow, state-centric focus embodied in the international system and society perspectives. ${ }^{79}$

Furthermore, it is important to stress that cosmopolitanism is not some utopian dream; in sharp contrast, many cosmopolitan principles already exist in international relations. For example, scholars such as Linklater and Richard Shapcott have used the idea of harm to highlight that a "global harm narrative" has already emerged in international relations. ${ }^{80}$ The reality is that states have managed to forge a common understanding on a "range of matters which belong to a lower moral register than visions of some supposedly universal conception of the good." ${ }^{11}$ In other words, although there is still a debate regarding what constitutes a universal good, states have come to an understanding over what constitutes a universal bad. It is here that the crime of genocide is of relevance. Although different societies have different views on what constitutes harm, there is a universal consensus regarding the crime of genocide. As Shapcott explains,

It follows that the more serious or fundamental the nature of the harm, the more likely it is to be identified as such by people in diverse situations. Starvation is a clearly harmful condition that is close to being both objectively identifiable (the point at which life can no longer continue) and commanding of a near universal consensus as to its harmful status. Likewise, having one's identity, or community of belonging, removed or destroyed (harmed), is also something that might well command such a consensus. Genocide is perhaps one value that states have agreed (in principle) overrides national sovereignty, thus recognising a universal crime (or harm) against communities as well as individuals. ${ }^{82}$

Both Shapcott and Linklater recognize genocide as a paradigm example of harm and claim that the UNCG represents a cosmopolitan harm convention. ${ }^{83}$ Moreover, they make the case that the principle of harm can be used to promote a global civilizing process that benefits not just states but humankind itself. ${ }^{84}$ Furthermore, as the statement suggests, this process has already begun and should not be seen as some abstract dream. Yes, we may live in an international society rather than an international community, but this does not mean that cosmopolitan principles do not exist within this society and that they cannot be further institutionalized in order to help bring about an international community.

It is the concept of humanity, therefore, that seems to represent a point of fracture between the international society approach outlined above and the international community approach upheld by cosmopolitans. For example, leading English School scholar Nicholas J. Wheeler has put forward a seminal text in which he claims that humanitarian intervention could be legitimate if it were to prevent crimes such as genocide. ${ }^{85} \mathrm{In}$ contrast, William Bain claims, "It seems as though Wheeler merely invokes humanity as a self-evident moral truth-the authority of which requires no further explanationwhich in the end cannot tell us the reasons why we should act to save strangers." 86 The statement is significant for it explains that in failing to justify the existence of humanity, English School scholars such as Wheeler fail to explain why we should act to save those targeted by crimes like genocide. In sharp contrast, cosmopolitans ask us to consider 
the Kantian understanding of humanity, which is built on the claim that human beings are inextricably connected: "a violation of rights in one part of the world is felt everywhere." 87 Again, one can see such thinking evident in the discourse; for example, Fergal Keane's analysis on the Rwandan Genocide led him to claim that "genocide killing in Africa diminishes us all." ${ }^{8}$ In so doing, Keane invokes the idea that an international community of humankind actually exists which reflects his worldview. This would be categorically rejected by realists.

To return briefly to the debate set out between Melvern and Wertheim at the start of this article, the cosmopolitan framework discussed here would ask policy makers not to calculate the cost-benefit analysis of genocide prevention based on the interests of the state but on the interest of humanity itself. Thus, while Wertheim is correct to highlight the difference between what is possible and what is plausible, one should not let the focus on the latter obscure the potential for the former. From a cosmopolitan perspective, Wertheim's approach places too much emphasis on the state-centric reality of how the world is, rather than how it should be. After all, when faced with the horror of genocide it seems perfectly acceptable to make the normative case that since states can cooperate, they should cooperate in order to stop genocide. But again, these perspectives stem from alternative worldviews, and it is impossible to prove (in the scientific sense) that one is right and the other wrong as this is a matter of judgment, not science.

As with the system and society perspectives discussed above, there are, of course, limitations and problems that need to be considered. The central concern with the international community perspective is the value it places on the concepts of humanity, human nature, and human essence to condemn acts such as genocide as inhuman.89 The problem with this worldview is that it is built on the assumption that humanity and human essence exist. ${ }^{90}$ One could, for example, claim that the widespread participation of "ordinary people" in the genocidal process highlights the tragic reality that such acts are, in fact, human. ${ }^{91}$ This somewhat profound philosophical argument was put into context in the aftermath of the Nazi atrocities as news and images of events began to filter through mainstream British society. After viewing a Daily Express exhibition on the horrors that took place in Belsen, one 30-year-old woman stated,

I'm afraid it didn't make me feel anti-German; it made me feel anti-humanity. Would the same have happened here, I wonder, if we'd had the same government? I've heard some violent anti-Semitic talk which makes me think it would. I feel it's the fault of humanity at large, not the Germans in particular. ${ }^{92}$

The statement highlights that just as one can appeal to the idea of humanity to condemn the crime of genocide, one can also appeal to the crime of genocide to refute the existence of a common humanity. Furthermore, even if realists and English School scholars were to accept that humanity does in fact exist, they would then question how we can realistically transform the present international system or international society into an international community. ${ }^{93}$ While cosmopolitan scholars offer normative claims, these problems demonstrate how this is an ongoing debate and that further research needs to be done.

In sum, cosmopolitans would tend to accept that we do not live in an international community; yet they uphold a commitment to cosmopolitan principles in the hope that a community of humankind can be established. While English School scholars would 
advocate the prevention of genocide on the grounds that this is a legal duty that has to be fulfilled, cosmopolitans would tend to claim that there is something bigger at stake: humanity. Yet at the same time, the concept of humanity is problematic. Whereas scholars such as Keane make the claim that genocide "diminishes us all," realists would simply question if this is true. If it is not, what does this tell us about the concept of humanity? If it is, how are we meant to transform the present international system into an international community? Thus, further dialogue on this issue is essential for it may be the case that even if humanity does not exist, this does not mean that we should not construct it, cherish it, and protect it. ${ }^{94}$

\section{Conclusion}

This article has examined three perspectives on genocide to illustrate how one's view of international relations shapes one's perception, interpretation, and understanding of genocide within it. This is a simple yet important point. For example, genocide scholars continually refer to the international community's failure to prevent genocide; yet it is clear that most IR scholars do not actually believe that an international community exists. Therefore, when genocide scholars use the term international community they seem to be simply repeating a political mantra which is often put forward by politicians for political purposes. ${ }^{95}$ Through an examination of the ideas of an international system, international society, and international community, this article revealed how alternative worldviews embody fundamentally different understandings of cooperation, power, justice, order, human nature, and so forth, which in turn shape perceptions of genocide. In other words, genocide is open for interpretation. This may seem somewhat shocking as some genocide scholars might claim that all scholars, policy makers, and laypeople should see genocide as a problem of the greatest magnitude. Yet the truth is that there is not one interpretation of genocide. Thus, the three perspectives outlined in this article help underline the magnitude of the task at hand as genocide prevention remains dependent on a consensus being forged among actors who do not share a common worldview.

Adrian Gallagher is a Lecturer in Security Studies at the University of Leeds. He completed a PhD funded by the UK's Economic and Social Research Council at the University of Sheffield in 2010. His monograph, Genocide and Its Threat to Contemporary International Order, is forthcoming with Palgrave Macmillan in February 2013.

\section{Notes}

1. Martin Wight, International Theory: The Three Traditions, eds. Gabriele Wight and Brian Porter (New York: Holmes and Meier, 1992). I am drawing more specifically here on Andrew Linklater's reformulation of Wight's three traditions, as Linklater equates the idea of realism with an international system, rationalism with an international society, and cosmopolitanism with an international community. See Andrew Linklater and Hidemi Suganami, The English School of International Relations: A Contemporary Reassessment (Cambridge: Cambridge UP, 2006), chap. 4.

2. See Andrew Linklater, Beyond Realism and Marxism: Critical Theory in International Relations (Hampshire: Macmillan, 1990); Tim Dunne, "Mythology or Methodology? Traditions in International Theory," Review of International Studies 19,3 (1993): 305-18; Richard Little, "The English School's Contribution to the Study of International Relations," European Journal of International Relations 6,3 (2000): 395422; Alex J. Bellamy, "Humanitarian Intervention and the Three Traditions," Global Society 17,1 (2003): 3-20; Barry Buzan, From International Society to World Society? English School Theory and the Social Structure of Globalisation (Cambridge: Cambridge UP, 2006); Ken Booth and Nicholas J. Wheeler, eds., The Security Dilemma (Palgrave Macmillan, 2007). Also, it should be noted that many scholars from outside these three traditions have also reflected on its value; see Alex Bellamy, ed., International Society and Its Critics (Oxford: Oxford UP, 2004). 
3. This debate followed the original article, Stephen Wertheim, "A Solution from Hell: The United States and the Rise of Humanitarian Interventionism, 1991-2003," Journal of Genocide Research 12,3-4 (2010): 149-72. This in turn led to Linda Melvern, "A Response to Stephen Wertheim's 'A Solution from Hell: The United States and the Rise of Humanitarian Interventionism, 1991-2003," Journal of Genocide Research 13,1-2 (2011): 153-7; Stephen Wertheim, "On Moralism and Rwanda: A Reply to Linda Melvern," Journal of Genocide Research 13,1-2 (2011): 159-63.

4. Wertheim, "On Moralism and Rwanda," 161.

5. Melvern, "A Response," 154.

6. Wertheim, "On Moralism and Rwanda," 162; also, Wertheim, "A Solution from Hell," 154-8.

7. It should be stressed here that the debate between Melvern and Wertheim raises an array of issues which cannot be addressed here. I am not claiming that Melvern is a normative theorist and that Wertheim is a realist; rather, I am simply highlighting how one's view of genocide prevention may reveal more than just one's understanding of genocide.

8. For a more in-depth analysis see Linda Melvern, A People Betrayed: The Role of the West in the Rwandan Genocide (London: Zed Books, 2009).

9. Wertheim, "On Moralism and Rwanda," 160.

10. A large proportion of the political science literature focuses on how alternative ontological and epistemological assumptions shape discourses that have an impact on political decision making. See Colin Hay, Political Analysis: A Critical Introduction (Hampshire: Palgrave, 2002).

11. The need for interdisciplinary research that draws on genocide studies and international relations is evident here. For a wonderful example of such analysis see Stephen Burgess, "The African Standby Force, Genocide, and International Relations Theory," Genocide Studies and Prevention 6,2 (2011): 121-33, http://dx.doi.org/10.3138/gsp.6.2.121.

12. See Hedley Bull's thoughtful introductory essay in Martin Wight, International Theory.

13. Andrew Linklater, "The English School," in Theories of International Relations, Scott Burchill et al., 4th ed. (New York: Palgrave Macmillan, 2009), 87.

14. The dotted lines between the three traditions aim to represent the idea of blurred boundaries. Notably, there is considerable work to be done on the relationship between these three concepts. See Ian Clark, International Legitimacy and World Society (New York: Oxford UP, 2007); Ken Booth, Theory of World Security (Cambridge: Cambridge UP, 2007); Barry Buzan, From International Society; Iver B. Neumann, "The English School and the Practices of World Society," Review of International Studies 27,3 (2001): 503-7.

15. See Linklater and Suganami, The English School, chap. 4.

16. See David Boucher's discussion in The Limits of Ethic in International Relations: Natural Law, Natural Rights and Human Rights in Transition (Oxford: Oxford UP, 2009), 7.

17. Eric M. Blanchard, "Why is there no Gender in the English School?," Review of International Studies 37,2 (2011): 855-79.

18. See Bull, introduction to Wight, International Theory, esp. xiii.

19. Wight, International Theory, 260.

20. This article uses the term realism as shorthand to refer to the array of voices found within the realist and neorealist traditions. To avoid confusion, this article will specify which it engages with when addressing each tradition. In essence, any such approach faces an unavoidable double-edged sword, as on the one hand, realism and neorealism are fundamentally different yet share certain commonalities, and on the other hand, neither realism nor neorealism speaks with a unified voice. This was aptly captured in Robert G. Gilpin, "The Richness of the Tradition of Political Realism," International Organization 38,2 (1984): 287-304.

21. For an empirical critique of realism see John A. Vasquez's updated analysis, The Power of Power Politics: From Classical Realism to Neotraditionalism (Cambridge: Cambridge UP, 1998). For an equally compelling theoretical rejection of realism as unrealistic see Booth, Theory of World Security, esp. 31-6.

22. Barry Buzan, "The Timeless Wisdom of Realism?," in International Theory: Positivism and Beyond, eds. Steve Smith, Ken Booth, and Marysia Zalewski (Cambridge: Cambridge UP) chap. 2.

23. Tim Dunne and Brian C. Schmidt, "Realism," in The Globalization of World Politics: An Introduction to International Relations, eds. John Baylis, Steve Smith, and Patricia Owens, 4th ed. (Oxford: Oxford UP, 2008), 92.

24. Linklater and Suganami, The English School, 117 (emphasis in the original).

25. For the neorealist view, see Kenneth Waltz, Theory of International Politics (New York: McGraw-Hill, 1979). For the realist view see Hans Morgenthau, revised by Kenneth W. Thompson, Politics amongst Nations: The Struggle for Power and Peace (New York: McGraw-Hill, 1985). For an analysis on the relationship between the two theories see Kenneth Waltz, Realism and International Politics (New York: 
Routledge, 2008), chap. 5. Notably, Mearsheimer developed an offensive neorealist theory which stipulates that since states can never know how much power they require to survive, they should simply continue to accumulate power-within reason, of course. John J. Mearsheimer, The Tragedy of Great Power Politics (London: Norton, 2001).

26. Alex Alvarez, Governments, Citizens, and Genocide: A Comparative and Interdisciplinary Approach (Indiana: Indiana UP, 2001), 137.

27. Matthew Jardine, East Timor: Genocide in Paradise (Tuscon: Odonian, 1995), 8 in Alvarez, Governments, 137.

28. "The Triumph of Evil," Frontline, 26 January 1999, http://www.pbs.org/wgbh/pages/frontline/shows/ evil/etc/script.html (accessed by Alvarez on 8 Apr 2000), cited in Alvarez, Governments, 137.

29. Dusko Doder and Louise Branson, Milosevic: Portrait of a Tyrant (New York: Free Press, 1999), 105, cited in Alvarez, Governments, 141.

30. See Adrian M. Gallagher, "A Clash of Responsibilities: Engaging with the Realist Critique of the R2P," Global Responsibility to Protect 4,2 (2012): 334-57.

31. Joseph M. Grieco, "Anarchy and the Limits of Cooperation: A Realist Critique of the Newest Liberal Institutionalism," International Organization 42,3 (1988): 485-507, 485.

32. For an analysis of the security dilemma, see Herbert Butterfield, History and Human Relations (London: Collins, 1951); John Herz, Political Realism and Political Idealism: A Study in Theories and Realities (Chicago: U Chicago P, 1951); Booth and Wheeler, Security Dilemma.

33. Morgenthau, Politics amongst Nations, 9.

34. This classic Athenian rationale comes from Thucydides, History of the Peloponnesian War, trans. Rex Warner (New York: Penguin, 1972), 405.

35. Morgenthau, Politics amongst Nations, 12.

36. The phrase "saving strangers" is taken from Nicholas J. Wheeler, Saving Strangers: Humanitarian Intervention in International Society (Oxford: Oxford UP, 2000). Wheeler is an advocate of humanitarian intervention and provides an apt critique of the realist position. For further analysis highlighting the problems involved, see Jennifer M. Welsh, "Taking Consequences Seriously: Objections to Humanitarian Intervention," in Humanitarian Intervention and International Relations, ed. Jennifer M. Welsh (New York: Oxford UP, 2006), chap. 4.

37. The idea of a Trojan horse is taken from Gareth Evans, Responsibility to Protect: Ending Mass Atrocity Crimes Once and for All (Washington: Brookings, 2008), 54.

38. For an overview see Bruce Jones, Carlos Pascual, and Stephen John Stedman, Power and Responsibility: Building International Order in an Era of Transnational Threat (Washington: Brookings Institution, 2009). Also, Maryann Cusimano Love, ed., Beyond Sovereignty: Issues for a Global Agenda (Boston: Wadsworth, 2007).

39. For a relevant analysis on the national interest see Wight, International Theory, chap. 6. Also, Scott Burchill, The National Interest in International Relations Theory (New York: Palgrave, 2005).

40. Interview with Henry Kissinger, Charlie Rose, PBS, 16 April 1998, cited in John G. Heidenrich, How to Prevent Genocide: A Guide for Policymakers, Scholars, and the Concerned Citizen (London: Praeger, 2001), 142.

41. It should be noted here that offensive neorealists such as John J. Mearsheimer would not be so willing to abandon their principles in favor of any such intervention, which again reveals the tragic nature of the system itself. See Mearsheimer, Tragedy.

42. For an analysis that goes beyond the simple reference to Thucydides and Machiavelli see Nicholas Rengger, "Realism, Tragedy, and Anti-Pelagian Imagination in International Political Thought," in Realism Reconsidered, ed. Michael Williams (Oxford: Oxford UP, 2007), 118-36.

43. Rationalism is used here as a shorthand for international society and does not refer to rationalism in the US IR sense of the word which is synonymous with rational choice theory. See Paul Keal, European Conquest and the Rights of Indigenous Peoples: The Moral Backwardness of International Society (Cambridge UP, 2003), introduction, esp. 4-5. For a discussion of Grotius see Hedley Bull, "The Importance of Grotius," in Hugo Grotius and International Relations, eds. Hedley Bull, Benedict Kingsbury, and Adam Roberts (Oxford: Clarendon, 1992).

44. The idea that the English School is realism-in-drag is taken from Robert Gilpin, "The Global Political System," in Order and Violence: Hedley Bull and International Relations, eds. John D. B. Miller and R. J. Vincent (Oxford: Clarendon, 1990), 112.

45. Linklater and Suganami, The English School, 117-8. For further discussion on international legitimacy see Thomas M. Franck, The Power of Legitimacy among Nations (Oxford UP, 1990); Ian Clark, Legitimacy in International Society (Oxford: Oxford UP, 2005); Hilary Charlesworth and Jean-Marc Coicaud, eds., Fault Lines of International Legitimacy (New York: Cambridge UP, 2010). 
46. Andrew Linklater, "Rationalism," in Theories of International Relations, eds. Scott Burchill et al., (London: Macmillan, 1996), 95.

47. This was famously expressed in Hedley Bull, Anarchical Society: A Study of Order in World Politics (Hampshire: Palgrave MacMillan, 2002). See also Buzan, From International Society.

48. Critics such as Martin Shaw highlight that this state-centric approach overlooks the complexities within states regarding the relationship between individuals and/or citizens and states; see Martin Shaw, Global Society and International Relations, Sociological Concepts and Political Perspectives (Cambridge: Polity, 1994), chap. 5. This will be returned to in the analysis of international community.

49. I am drawing here from Clark's understanding of legitimacy and rightful conduct set out in Clark, Legitimacy in International Society.

50. Evans, Responsibility to Protect, 15-9.

51. For a chronological analysis see Evan Luard, "The Origins of International Concern over Human Rights," in The International Protection of Human Rights, ed. Evan Luard (London: Thames and Hudson, 1967). For a contemporary analysis on humanitarian intervention see Gary J. Baas, Freedom's Battle: The Origins of Humanitarian Intervention (London: Knopf, 2008).

52. William A. Schabas, Genocide in International Law (Cambridge: Cambridge UP, 2000), 14-50.

53. For an analysis on the impact of the Nazi genocide on human rights see Richard Falk, Achieving Human Rights (London: Routledge, 2009), chap. 6. For its impact on racial equality see R. J. Vincent, "Racial Equality," in The Expansion of International Society, eds. Hedley Bull and Adam Watson (Oxford: Clarendon, 1984).

54. For a scathing analysis which addresses reactions in the Cold War see Leo Kuper, Genocide and its Political Use in the Twentieth Century (New Haven: Yale UP, 1982), 161-85. For a more modern overview which is just as critical see Adam Lebor, "Complicity with Evil": The United Nations in the Age of Modern Genocide (London: Yale UP, 2006).

55. For an overview of the relevant debates see Thomas G. Weiss, Humanitarian Intervention (Cambridge: Polity, 2007); Jennifer M. Welsh, ed., Humanitarian Intervention in International Relations (Oxford: Oxford UP, 2006); D. K. Chatterjee and D. E. Scheid, eds., Ethics and Foreign Intervention in International Society (Cambridge: Cambridge UP, 2003); J. L. Holzgrefe and Robert O. Keohane, Humanitarian Intervention: Ethical, Legal and Political Dilemmas (Cambridge: Cambridge UP, 2003).

56. Wheeler, Saving Strangers, 11 (emphasis in the original).

57. James Mayall, ed., The New Interventionism, 1991-1994: United Nations Experience in Cambodia, Former Yugoslavia and Somalia (Cambridge: Cambridge UP, 1996); and Thierry Tardy, "The UN and the Use of Force: A Marriage Against Nature," Security Dialogue 38,1 (2007): 49-70.

58. See Independent International Commission on Kosovo, The Kosovo Report: Conflict, International Response, Lessons Learned (Oxford: Oxford UP, 2000), 168.

59. See Alex J. Bellamy, Global Politics and the Responsibility to Protect (New York: Routledge, 2011).

60. Robert Jackson, The Global Covenant: Human Conduct in a World of States (Oxford: Oxford UP, 2000).

61. Jackson, Global Covenant, 410. Whilst not using this phrase as such, Jackson puts forward a strong normative argument that uses the idea of humanity to oppose humanitarian intervention.

62. See Wheeler, Saving Strangers; also, Alex J. Bellamy, "Military Intervention," in The Oxford Handbook of Genocide Studies, eds. Donald Bloxham and A. Dirk Moses (New York: Oxford UP, 2010), 597-616.

63. Article 2 (7) states: "Nothing contained in the present Charter shall authorize the United Nations to intervene in matters which are essentially within the domestic jurisdiction of any state or shall require the Members to submit such matters to settlement under the present Charter; but this principle shall not prejudice the application of enforcement measures under Chapter VII."

64. See Matthew S. Weinert, "Reframing the Pluralist-Solidarist Divide," Millennium: Journal of International Studies 40,1 (2011): 21-41; also, John Williams, "Pluralism, Solidarism and the Emergence of World Society in English School Theory," International Relations 19,1 (2005): 19-38.

65. Ian Clark, International Legitimacy. The idea of a "tolerable consensus" being forged among relevant actors in this context allows for much-needed flexibility. Essentially, more than a consensus among the permanent five is needed and the rise of "new" powers such as India, Brazil, and Turkey, as well as existing regional organizations and none UN Security Council powers such as Germany and Japan, will be vital in order for a long-term genocide prevention strategy to be implemented. For a contemporary view on the complexities of legal humanitarian intervention see Ian Hurd, "Is Humanitarian Intervention Legal? The Rule of Law in an Incoherent World," Journal of Ethics and International Affairs 23,3 (2011): 293-313.

66. Paul Keal, European Conquest. Perhaps somewhat bizarrely, the author does not engage with Zygmunt Bauman's seminal thesis Modernity and the Holocaust (Cambridge: Polity, 1989).

67. Obviously, this is adapted from the title of Keal's book. 
68. This of course can be questioned and I feel that there is fascinating research to be done on this thesis and how it relates to Mark Levene's Genocide in the Age of the Nation State, vol. 1, The Meaning of Genocide (London: I. B. Tauris, 2005); also, Mark Levene, "From Past to Future: Prospects for Genocide and its Avoidance in the Twenty-First Century," in Bloxham and Moses, Oxford Handbook, 638-59.

69. Hurrell, On Global Order, 27.

70. This is an ongoing process; see UN Secretary-General Ban Ki-moon, "Implementing the Responsibility to Protect" (A/63/67, 2009).

71. Tim Dunne, "Sociological Investigations: Instrumental, Legitimist and Coercive Interpretations of International Society," Millennium 30,1 (2001): 67-91. This can be traced back to competing moral visions embodied within the English School approach; see Nicholas J. Rengger, "Seeing (Double) in the Darkness: The Moral Vision of the Anarchical Society," in The Anarchical Society in a Globalized World, eds. Richard Little and John Williams (New York: Palgrave, 2006): 35-50.

72. Wight, International Theory, 267.

73. The idea that revolutionism acts to remind the other two traditions that the existing state-centric system is morally deficient is taken from Andrew Linklater, Beyond Realism and Marxism: Critical Theory in International Relations (Hampshire: Macmillan, 1990), 8.

74. Linklater and Suganami, The English School, 117.

75. See Garret W. Brown, "State Sovereignty, Federation and Kantian Cosmopolitanism," European Journal of International Relations 11,4 (2005): 495-522.

76. Garret W. Brown, "Bringing the State Back into Cosmopolitanism: The Idea of Responsible Cosmopolitan States,” Political Studies Review 9,1 (2011): 53-66.

77. Shaw, Global Society, 126.

78. Ibid. This is a theme developed throughout the book.

79. To go back to Figure 1, there is further work needed to be done on the relationship between concepts such as international society, international community, world society, and human society.

80. The idea of a "global harm narrative" is taken from Andrew Linklater, "Human Interconnectedness," International Relations 23,3 (2009): 481-97, 491.

81. Linklater and Suganami, The English School, 177. For an overview of debates over existing cosmopolitanism see Pheng Cheah and Bruce Robbins, eds., Cosmopolitics: Thinking and Feeling beyond the Nation (Minnesota: Minnesota UP, 1998), especially part 2, "Belonging to a World: Actually Existing Cosmopolitanism?," 117-229.

82. (This previous sentence needs to be deleted) Richard Shapcott, "Anti-Cosmopolitanism, Pluralism and the Cosmopolitan Harm Principle,” Review of International Studies 34,2 (2008): 185-205, 198.

83. For Linklater's position, see Linklater and Suganami, The English School, 181; see also chap. 6, "The Sociology of State-Systems.”

84. Andrew Linklater, The Problem of Harm in World Politics: Theoretical Investigations (Cambridge: Cambridge UP, 2011), 23.

85. Wheeler, Saving Strangers.

86. William Bain, "One Order, Two Laws: Recovering the 'Normative' in English School Theory," Review of International Studies 33,4 (2007): 557-75, 561.

87. Immanuel Kant, "Perpetual Peace," in Hans Reiss, ed., Kant's Political Writings (Cambridge: Cambridge UP, 1970), 170 [8:360], cited in Garrett W. Brown, Grounding Cosmopolitanism: From Kant to the Idea of a Cosmopolitan Constitution (Edinburgh: Edinburgh UP, 2009), 1 (emphasis in original).

88. Fergal Keane, Season of Blood: A Rwandan Journey (London: Penguin, 1995), 30.

89. Norman Geras, "Genocide and Crimes against Humanity," in Genocide and Human Rights: A Philosophical Guide, ed. John K. Roth(New York: Palgrave Macmillan, 2005), chap. 14; also, Norman Geras, The Contract of Mutual Indifference, Political Philosophy After the Holocaust (London: Verso, 1999).

90. For a seminal critique see Richard Rorty, Contingency, Irony and Solidarity (Cambridge: Cambridge UP, 1989). For an overview of this debate which notably draws on both Rorty and Geras among others, see The Limits of Ethics in International Relations, Natural Law, Natural Rights, and Human Rights in Transition (Oxford: Oxford UP, 2009), chap. 9.

91. The term and the idea of ordinary people committing such acts are taken from Christopher Browning, Ordinary Men: Reserve Police Battalion 101 and the Final Solution in Poland (London: Penguin, 2001).

92. Joanne Reilly, Belsen: The Liberation of a Concentration Camp (London: Routledge, 1998), 69.

93. For example, Andrew Linklater's work, which has been discussed extensively here, led one scholar to claim that ideas regarding the transformation of the international system into a community was nothing more than fantasy theory; see Randall L. Schweller, "Fantasy Theory," Review of International Studies 25,1 (1999): 147-50.

94. Ken Booth claims that we should invent humanity; see Booth, Theory of World Security, 379-80. 
95. For example, Condoleezza Rice once referred to the "illusionary international community" in order to substantiate the US objective of furthering the national interest of the United States through unilateral action; see Joseph Nye, "The American National Interest and Global Public Goods," International Affairs 78,2 (2002): 233-44, 236. Then in 2010, the WikiLeaks scandal showed that the US had framed the event as an "attack against the international community" in order to gain the necessary international consensual support; see "Wikileaks Diplomat Cables Release 'Attack on World," BBC News, 29 November 2010, http://www.bbc.co.uk/news/world-us-canada-11868838 (accessed 22 May 2011). 